\title{
Technology of integrated processing of fruit raw material in the small enterprise setting
}

\author{
Tatyana Krapiva ${ }^{1, *}$, Larisa Mayurnikova ${ }^{1}$, Arkadiy Koksharov ${ }^{1}$, Sergey Novoselov $^{2}$, and Galina Gubanenko ${ }^{3}$ \\ ${ }^{1}$ Kemerovo State University, 650056 Krasnaya 6, Russia \\ ${ }^{2}$ Altai Technical University named after I. I. Polzunov, 656038 Lenina avenue 46, Russia \\ ${ }^{3}$ Siberian Federal University, 660041, Svobodny pr. 79, Russia
}

\begin{abstract}
The scientific and technological development of Russia is aimed at food security and food independence of the country. The problem is solved by using local raw materials, as well. Of high priority is the creation of food products with the pre-set functional properties. The government provides grant support for the projects and scientific programs of innovation activities. The challenge consists in rapid transition from the research results to their implementation. The task is effectively solved within the frames of $R \& D$ innovative projects in the system: "science and education - production -- market". The specific features of growing and harvesting plant raw materials lie in their season character and a small scale. It actualizes its processing with the purpose of obtaining new food products in the small enterprise setting. The research on the technology of integrated processing of high cranberry was done. It involved whole berries pre-drying, cutting and further use of powder-like mixture in the syrup preparation. Modes and parameters for high cranberry drying are brought out: temperature $80^{\circ} \mathrm{C}$, time period -72 hours with purification intensity of $30 \%$ of air volume an hour; kibbling of dry berries to powdery condition with the particle size of $0.001 \mathrm{~mm}$. Rational technological modes and parameters for ready-made syrup are established: mass fraction of sugar syrup dry substances $-55 \%$; the proportion "sugar syrup: high cranberry powder" in the recipe is 10:1.15; syrup cooking time - 30 minutes. Comparative analysis of nutritional value of fresh and dried high cranberry was carried out. The research has shown a high content of polyunsaturated fatty acids in the latter, that proves the practicability of high cranberry integrated processing.
\end{abstract}

\section{Introduction}

Under the conditions of innovative development of the society sustainment sector it is timely to provide the regional population with healthy nutrition, based on the technology of integrated processing of traditional raw material resources, considering food behavior patterns [1]. Attention is focused upon the targeted support to young scientists and specialists in the field of science, scientific and technical and innovation activities which result in social and economic development. For achieving results in top-priority areas the integral programs and projects are formed that include all the stages of the innovation cycle: from obtaining fundamental knowledge to its application in developing new technologies and products and their marketing-out $[2,3]$.

Of high priority is knowledge-intensive production where, for strengthening the competitive positions, the ability to constantly renew the product is of crucial importance. It is achieved through implementation of "product technologies", i.e. creating and promoting allnew goods. In this respect, higher value belongs to small and medium-sized businesses as they are the most conductive to rapid changes in technologies and products. Small and medium-sized enterprises can make the switch in their specialization, whichever narrow focused $[4,5,6,7]$.

The government assistance for innovative development of small entrepreneurship is represented by grant support system through the Fund contributing to the development of small enterprises in scientific and technical sphere, and realization of priority area programs $[8,9,10,11]$. The similar ways are commonly available abroad [12, 13, 14, 15].

The mandatory condition for new product development in the frames of the innovative project is functioning of the system: "science and education production - market", as an aspect of the triple helix model: "government - science - business". In the model suggested the innovative project is the synthesis of technical and technological pattern for the new product and business application pattern, and reflects the interests and functions of the developer, manufacturer and market with the support of government structures $[16,17]$.

The formation of knowledge base about the product projected, at every stage -- "from the idea to the consumer" -- is currently important while developing new nutritional items $[18,19]$. At the first stage the set

\footnotetext{
* Corresponding author: t.krapiva@mail.ru
} 
of knowledge about raw material resources and prospects for their use is substantial. Previously, technologies of integrated processing of plant raw materials were also of interest, but under small entrepreneurship development they become highly topical. For many regions of the Russian Federation, including Western Siberia, with the developed industrial infrastructure and marked absence of ecological wellbeing, this is one of the approaches to optimum nutrition through research and development of new functional products.

West-Siberian region of Russia has a vast territory rich in primary natural resources of medicinal and technical, fruit raw materials. Widely available samples of fruit raw materials, such as sea buckthorns, high cranberry, field-ash growing at scales large enough for commercial processing, are of most interest. Saturation of food market with surrogate products, among them canned fruit and berries of foreign and home production, lead to lowering of the organizational level of origination and processing of harvested and collected raw material. There are prospects for the solution of problem by means of developing the technologies of integrated processing of fruit raw material in the small enterprise setting.

\section{Subjects and methods of research}

The subject of the research was high cranberry (Viburnum opulus) growing on the territory of the Siberian Federal District. Collecting was carried out in November during early autumn frost at the background temperature of minus $20 \mathrm{C}$. For experimental research the fruits of fresh-frozen and dried cut-up high cranberry were used.

Fatty acid composition analysis of oils was made using gas-liquid chromatography method (GLC). The techniques include: disengagement of free fatty acids via saponification of glycerides that are constituents of the oils under study, with $60 \%$ alkali water and subsequent treatment with $10 \%$ hydrochloric acid aqueous solution; their methylation with diazomethane for obtaining corresponding methyl esters, having lower boiling temperatures than the acids themselves; GLC-separation and treatment of the chromatograms obtained.

\section{Results and discussion}

High cranberry is a valuable nutritive and medicinal plant. High cranberry fruits are characterized by good keeping qualities of biologically active substances while being on the shrubs and during the process of storage of harvest taken in, which is of great practical importance for their picking and processing [20].

High cranberry hardly has any application in the production of nonalcoholic beverages from mono-raw material (juices, nectars, syrups) due to presence of viburnin, causing the fruits' bitterness. To a larger extent, high cranberry fruits are used as blend ingredients in the production of confectioneries and sauces $[21,22,23,24]$. The patent literature analysis has revealed the availability of syrup technologies based on high cranberry juices and non-availability of those based on the whole fruits.

Juices are semi-processed materials widely used in syrup recipes, pulpy juice being the healthiest. In making juices nonedible parts of fruits and vegetables (skins, seeds, pits) are considered inferior and they are removed for the purpose of heightening the value of the product. However, the high cranberry pit is of fairly high nutritional value and contains substances necessary for the human organism, such as fatty acids, which highlights the practicability of using the whole high cranberry fruits in syrup manufacturing.

The research studied high cranberry pulpy juice and fatty acid composition of high cranberry pits that are going to be used as syrup recipe ingredients. Dry substance content in high cranberry pulpy juice is $15.0 \pm 0.1 \mathrm{mg} / 100 \mathrm{~g}$. The carbohydrate composition of the juice under study is presented by two subgroups: monosaccharides and polysaccharides. Polysaccharides take a significant place in berries' chemical composition, especially pectin substances, which alongside with cellulose and hemicellulose, make up the basis for plant cell surface and tissues. Pectin substances of high cranberry pulpy juice are presented by pectin $(1.63 \pm 0.11 \mathrm{mg} / 100 \mathrm{~g})$ and protopectin $(1.22 \pm 0.06 \mathrm{mg} / 100 \mathrm{~g})$. Pectin substances are known to be undesirable in manufacturing clarified juices. They worsen filtration, flocculate during storage, and make juices and beverages cloudy. This disadvantage can be avoided when making pulpy juices or using whole berries, i. g. dried ones and cut to powdery state. The etherification degree of high cranberry pectin substances amounts to $55 \%$, that says for good gelling power.

Nonvolatile acids, along with sugars and aromatic substances make the taste of fruits. While investigating quantitative and qualitative composition of the organic substances of high cranberry juices, malic $(0.73 \pm 0,02 \mathrm{mg} / 100 \mathrm{~g})$, citric, $(0.33 \pm 0.02 \mathrm{mg} / 100 \mathrm{~g})$, valeric $(0.34 \mathrm{mg} / 100 \mathrm{~g})$ acids were found; tartaric acid and ethane diacid were detected in trace amounts.

The content of juice tocopherols which are only synthesized in plants, is of interest. E vitamin, in its chemical nature, also belongs to the group of tocopherols existing in three forms: $\alpha, \beta$ и $\gamma$. The content of tocopherols in high cranberry pulpy juice is $0.3 \mathrm{mg} / 100 \mathrm{~g}$. High content of tocopherols in pulpy juices can be attributed to the fact that they are, to a higher extent, present in juice pulp abounding in fruit oil. E vitamin stabilizes and protects unsaturated lipids from excessive oxidation, which is a positive point for long-term storage products to which syrups can be attributed. Carotene content makes up as much as $0.12 \pm 0.01 \mathrm{mg} / 100 \mathrm{~g}$.

Considering that in developing the syrup formula and technologies the main components are dried and cut high cranberry fruits, the fatty acid composition of high cranberry oils obtained from the pits was studied. For obtaining the oil from high cranberry pits hexane extraction of dried and cut fruits was used, with subsequent removing of the solvent by vacuum. Depending on the high cranberry species, the pit constitutes from $15.0 \%$ to $20.4 \%$ of edible part volume 
of the fruit. The results of estimating fatty acid composition of high cranberry oil are given in Table 1 .

Table 1. Fatty acid composition of high cranberry oil.

\begin{tabular}{|c|c|}
\hline $\begin{array}{c}\text { Acids in high cranberry oil (low-molecular }\left(\mathbf{C}_{4}-\right. \\
\left.\mathbf{C}_{\mathbf{1 0}}\right)\end{array}$ & $\mathbf{m g} / \mathbf{1 0 0 g}$ \\
\hline Palmitic $\left(\mathrm{C}_{16: 0}\right)$ & 0.2 \\
\hline Palmitoleic $\left(\mathrm{C}_{16: 1}\right)$ & 3.6 \\
\hline Oleic $\left(\mathrm{C}_{18: 1}\right)$ & 40.9 \\
\hline Linoleic $\left(\mathrm{C}_{18: 2}\right)$ & 55.3 \\
\hline
\end{tabular}

The oils' physiological value is known to be determined by the availability of essential polyunsaturated acids (linolic, linoleic, arachidonic). More specifically, prostaglandins participating in many life-sustaining processes of the body, including its reproductive activity, are synthesized from them [25].

High cranberry oil is characterized by large amount of linolic acid available $-55.3 \%$. There are also lauric $\left(\mathrm{C}_{12: 0}\right)$, myristic $\left(\mathrm{C}_{14: 0}\right)$, stearic $\left(\mathrm{C}_{18: 0}\right)$ and linoleic $\left(\mathrm{C}_{18: 3}\right)$ acids in it. High content of unsaturated acids present proves the practicability of using all parts of the high cranberry fruit in syrup manufacturing.

The advantage of syrups produced from fruit raw material is the possibility to manufacture the wide range of them varying by the kind of raw material used: fresh, frozen, dried, whole, cut; by the composition: samename syrups, blended and fortified ones, etc. With the purpose of determining the advantages and disadvantages of syrups made from source raw material of different commodity forms the research was carried out on development and evaluation of the quality of the fresh high cranberry syrup and dried and cut high cranberry syrup.

High cranberry fruits were dried in thermal driers at the temperature of $80^{\circ} \mathrm{C}$ during 72 hours with purification intensity of $30 \%$ of air volume an hour. A greater speed can cause the destruction of high cranberry BAS and loss of fatty acids. With a lower speed the development of molds in the poorly aerated corners of the driers were observed (Table 2).

Table 2. Parameters of drying for high cranberry fruits.

\begin{tabular}{|l|l|l|}
\hline \multicolumn{4}{|c|}{ Parameters of drying } \\
\hline $\begin{array}{l}\text { Temperature } \\
\leq \quad 80^{\circ} \mathrm{C} \\
\left(60^{\circ} \mathrm{C}\right)\end{array}$ & Temperature $80^{\circ} \mathrm{C}$ & $\begin{array}{l}\text { Temperature } \geq 80^{\circ} \mathrm{C} \\
\left(100^{\circ} \mathrm{C}\right)\end{array}$ \\
\hline $\begin{array}{l}\text { Less than } \\
80^{\circ} \mathrm{C}-\text { not } \\
\text { practicable }\end{array}$ & $\begin{array}{l}\text { during } 72 \text { hours } \\
\text { with purification } \\
\text { intensity of } 30 \% \text { of } \\
\text { air volume an hour }\end{array}$ & $\begin{array}{l}\text { At a higher temperature } \\
- \text { possible destruction } \\
\text { of high cranberry BAS } \\
\text { and loss of fatty acids }\end{array}$ \\
\hline
\end{tabular}

The complexity of technology for manufacturing syrups from whole high cranberry fruits lies not only in their drying, but also in cutting, as the pit contains a large amount of oil. Parameters for cutting dried high cranberry were investigated with reference to the small enterprise capabilities, the shredder power being $27 \mathrm{~kW}$, kibbling duration -4 hours.

Three fractions were obtained from dried fruit powder, being allowed to pass through sieves with the mesh size of: $0.001 \mathrm{~mm}, 0.01 \mathrm{~mm}$ и $0.02-0.05 \mathrm{~mm}$.
The behavior in water solution of the three powder fractions obtained from whole high cranberry fruits (model mixtures) was studied. The mixtures were made using high cranberry powder and water at the ratio 1:10. The water temperature was from 20 to $80^{\circ} \mathrm{C}$ at $20^{\circ} \mathrm{C}$ intervals. The results of the organoleptic examination of the mixtures obtained are given in Table 3 .

Table 3. Organoleptic data for model mixtures of high cranberry powder.

\begin{tabular}{|c|c|c|c|}
\hline \multirow{2}{*}{$\begin{array}{l}\text { Water } \\
\text { tempe } \\
\text { rature }\end{array}$} & \multicolumn{3}{|c|}{$\begin{array}{l}\text { Model solutions' appearance, consistency, color, } \\
\text { smell with particle size of high cranberry powder }\end{array}$} \\
\hline & $0.001 \mathrm{~mm}$ & $0.01 \mathrm{~mm}$ & $0.02-0.05 \mathrm{~mm}$ \\
\hline $20^{\circ} \mathrm{C}$ & $\begin{array}{l}\text { Heterogeneous } \\
\text { mass, badly } \\
\text { humidified, with } \\
\text { balls of particles } \\
\text { of high cranberry } \\
\text { powder. Red- } \\
\text { brown color. } \\
\text { Faint odor of } \\
\text { high cranberry } \\
\text { powder. }\end{array}$ & $\begin{array}{l}\text { Heterogeneous } \\
\text { mass, badly } \\
\text { humidified, with } \\
\text { balls of particles } \\
\text { of high cranberry } \\
\text { powder. Red- } \\
\text { brown color. } \\
\text { Faint odor of } \\
\text { high cranberry } \\
\text { powder. }\end{array}$ & $\begin{array}{l}\text { Homogeneous } \\
\text { two-layer mass } \\
\text { with observed } \\
\text { large particles of } \\
\text { high cranberry } \\
\text { powder. Red- } \\
\text { brown color. } \\
\text { Faint odor of } \\
\text { high cranberry } \\
\text { powder. }\end{array}$ \\
\hline $40^{\circ} \mathrm{C}$ & $\begin{array}{l}\text { Homogeneous } \\
\text { mass with balls } \\
\text { of particles of } \\
\text { high cranberry } \\
\text { powder } r \text { Red- } \\
\text { brown color. } \\
\text { Odor of high } \\
\text { cranberry } \\
\text { powder Layer } \\
\text { formation - in } \\
\text { 90min. }\end{array}$ & $\begin{array}{l}\text { Homogeneous } \\
\text { mass with balls } \\
\text { of particles of } \\
\text { high cranberry } \\
\text { powder } \quad \text { Red- } \\
\text { brown color. } \\
\text { Odor of high } \\
\text { cranberry } \\
\text { powder Layer } \\
\text { formation - in } \\
60 \text { min. }\end{array}$ & $\begin{array}{l}\text { Homogeneous } \\
\text { two-layer mass } \\
\text { with observed } \\
\text { large particles of } \\
\text { high cranberry } \\
\text { powder. Red- } \\
\text { brown color. } \\
\text { Odor of high } \\
\text { cranberry } \\
\text { powder. }\end{array}$ \\
\hline $60^{\circ} \mathrm{C}$ & $\begin{array}{l}\text { Homogeneous } \\
\text { mass, well } \\
\text { humidified, with } \\
\text { stable } \\
\text { consistency of } \\
\text { suspended } \\
\text { particles of high } \\
\text { cranberry } \\
\text { powder. Rich } \\
\text { red-brown color. } \\
\text { Odor of high } \\
\text { cranberry is } \\
\text { pleasant, well- } \\
\text { defined. Layer } \\
\text { formation - in } \\
\text { 120min. }\end{array}$ & $\begin{array}{l}\text { Homogeneous } \\
\text { mass, well } \\
\text { humidified, with } \\
\text { stable } \\
\text { consistency of } \\
\text { suspended } \\
\text { particles of high } \\
\text { cranberry } \\
\text { powder. Rich } \\
\text { red-brown color. } \\
\text { Odor of high } \\
\text { cranberry is } \\
\text { pleasant, well- } \\
\text { defined. Layer } \\
\text { formation - in } \\
\text { 80min. }\end{array}$ & $\begin{array}{l}\text { Homogeneous } \\
\text { three-layer mass } \\
\text { with observed } \\
\text { large particles of } \\
\text { high cranberry } \\
\text { powder. Red- } \\
\text { brown color. } \\
\text { Odor of high } \\
\text { cranberry. }\end{array}$ \\
\hline $80^{\circ} \mathrm{C}$ & $\begin{array}{l}\text { Homogeneous } \\
\text { mass, with stable } \\
\text { consistency of } \\
\text { suspended } \\
\text { particles of high } \\
\text { cranberry } \\
\text { powder. Rich } \\
\text { red-brown color. } \\
\text { Odor of high } \\
\text { cranberry is } \\
\text { pleasant. Layer } \\
\text { formation - in } \\
\text { 120min. }\end{array}$ & $\begin{array}{l}\text { Homogeneous } \\
\text { mass, with stable } \\
\text { consistency of } \\
\text { suspended } \\
\text { particles of high } \\
\text { cranberry } \\
\text { powder. Rich } \\
\text { red-brown color. } \\
\text { Odor of high } \\
\text { cranberry. Layer } \\
\text { formation - in } \\
\text { 80min. }\end{array}$ & $\begin{array}{l}\text { Homogeneous } \\
\text { three-layer mass } \\
\text { (oil, liquid, } \\
\text { powder) with } \\
\text { observed large } \\
\text { particles of high } \\
\text { cranberry } \\
\text { powder. Red- } \\
\text { brown color. } \\
\text { Odor of high } \\
\text { cranberry. }\end{array}$ \\
\hline
\end{tabular}

Comparative analysis of the model mixtures organoleptic data has shown that there is possibility to use the high cranberry powder with the particle size of $0.001 \mathrm{~mm}$ in further research. Raise of water temperature 
positively influences the solubility. The hypothesis is made that layer formation observed during the preparation of solution can be avoided by means of thermal effect used in the technological process of deriving finished syrup from high cranberry powder. By the course of brewing, changes in the structural and mechanical properties of powder particles occur, which facilitates the buildup of the syrup colloidal structure.

It is known that for the desired consistency of the product nutrient supplements are used in recipes, including natural ones: gelatin, pectin, agaroids, etc. In nonalcoholic syrups the thickening agent is primarily sugar (sugar syrup). The influence of sugar syrup concentration on the stability of the colloidal system of high cranberry solid particles in the syrup's liquid medium was investigated.

To determine the ratio of sugar syrup to high cranberry powder in the recipe of the finished high cranberry syrup, samples were prepared in which the following proportions were varied - sugar syrup (\% $\mathrm{d}$. s.) : dried and cut high cranberry powder (mg). The content of dry substances in the sugar syrup samples was from $50 \%$ to $65 \%$ at the $5 \%$ interval. The content of dried and cut high cranberry powder in the samples was from $10.0 \mathrm{mg}$ to $12.0 \mathrm{mg}$ at the 0.5 interval. The syrup samples were left for storage and the consistency of the finished produce (stability - layering) was observed for 12 months (Table 4).

Table 4. Consistency of high cranberry syrup in during storage.

\begin{tabular}{|c|c|c|c|}
\hline \multirow{2}{*}{$\begin{array}{l}\text { Weight } \\
\text { fraction } \\
\text { of } d \text {. s. } \\
\text { in the } \\
\text { syrup, } \\
(\%)\end{array}$} & \multicolumn{3}{|c|}{$\begin{array}{l}\text { Size of high cranberry powder particles in the } \\
\text { syrup }\end{array}$} \\
\hline & $\begin{array}{l}\text { Sample №1 } \\
\text { Particle size } \\
0.001 \mathrm{~mm}\end{array}$ & $\begin{array}{l}\text { Sample №2 } \\
\text { Particle size } \\
0.01 \mathrm{~mm}\end{array}$ & $\begin{array}{l}\text { Sample №3 } \\
\text { Particle size } \\
0.02-0.05 \mathrm{~mm}\end{array}$ \\
\hline 50 & $\begin{array}{l}\text { Marked } \\
\text { layer } \\
\text { formation, } \\
\text { suppressed } \\
\text { with } \\
\text { agitation }\end{array}$ & $\begin{array}{l}\text { Layer } \\
\text { formation } \\
\text { during storage. } \\
\text { In } 12 \text { months of } \\
\text { storage a } \\
\text { marked } \\
\text { boundary line } \\
\text { between layers } \\
\text { is observed: } 1 \\
\text { layer - oil, } 2- \\
\text { liquid part, } 3- \\
\text { sediment of } \\
\text { high cranberry } \\
\text { solid particles. }\end{array}$ & $\begin{array}{l}\text { Layer } \\
\text { formation } \\
\text { during storage. } \\
\text { In } 12 \text { months of } \\
\text { storage a } \\
\text { marked } \\
\text { boundary line } \\
\text { between layers } \\
\text { is observed: } 1 \\
\text { layer - oil, } 2- \\
\text { liquid part, } 3- \\
\text { sediment of } \\
\text { high cranberry } \\
\text { solid particles. }\end{array}$ \\
\hline 55 & $\begin{array}{l}\text { Marked } \\
\text { layer } \\
\text { formation, } \\
\text { easily } \\
\text { suppressed } \\
\text { with } \\
\text { agitation } \\
\end{array}$ & The same & The same \\
\hline 60 & The same & The same & The same \\
\hline 65 & The same & The same & The same \\
\hline
\end{tabular}

The sensory analysis of fresh-made syrups from dried and cut high cranberry powder has allowed to establish sound technological modes and parameters: size of dried and cut high cranberry powder particles $-0.001 \mathrm{~mm}$; Weight fraction of dry substances in the syrup - 55\%; the recipe proportion of sugar syrup to high cranberry powder - 10:1.15. When making the blend dried and cut high cranberry powder is placed into water with the temperature of $60^{\circ} \mathrm{C}$; the mass is stirred with subsequent brewing of syrup during 30 minutes. Storage life of "Kalinovyi" syrup is 12 months. The syrup's high stability is attributable to the presence of natural antioxidants: carotenoids, fatty oils contained in the high cranberry fruit's pit. As for technological modes and parameters, hot process filling is recommended for better storage.

Source raw materials for syrup manufacturing: fresh and dried/cut high cranberry - have their advantages and disadvantages. Fresh high cranberry has a full set of nutritive substances, characteristic of the species. However, syrup from the fresh high cranberry fruit is only obtained using the juice and the pulp, removing the pit. The pit, for its part, contains a number of useful substances, including oil. The comparative analysis of the nutrition value of the manufactured finished syrups is given (Table 5).

Table 5. The nutrition value of the syrups from fresh and dried fruits of high cranberry.

\begin{tabular}{|c|c|c|}
\hline \multirow{2}{*}{$\begin{array}{c}\text { Nutrient } \\
\text { substances }\end{array}$} & \multicolumn{2}{|c|}{ Syrups (in $100 \mathrm{~g}$ ) } \\
\hline & $\begin{array}{c}\text { "Kalinovyi" (from } \\
\text { dried/cut high } \\
\text { cranberry fruits) }\end{array}$ & $\begin{array}{l}\text { «Kalina zimnyaya" } \\
\text { (from the juice of } \\
\text { fresh high cranberry } \\
\text { fruits) }\end{array}$ \\
\hline $\begin{array}{l}\text { Ascorbic acid, } \\
\text { mg }\end{array}$ & $3.5 \pm 0.1$ & $5.6 \pm 0.2$ \\
\hline $\begin{array}{l}\text { Polyphenols } \\
\text { (sum), g }\end{array}$ & $125 \pm 11.3$ & $165 \pm 13.2$ \\
\hline $\begin{array}{c}\text { Carotenoids, } \\
\mathrm{mg}\end{array}$ & $0.15 \pm 0.05$ & $0.11 \pm 0.02$ \\
\hline $\begin{array}{l}\text { Pectin sub-s } \\
\text { (overall), mg }\end{array}$ & $1.6 \pm 0.06$ & $1.8 \pm 0.03$ \\
\hline $\begin{array}{c}\text { Fatty acid } \\
\text { composition: }\end{array}$ & & \\
\hline $\begin{array}{c}\text { Lauric } \mathrm{C}_{12-0} \\
\mathrm{mg}\end{array}$ & 0.02 & Not found \\
\hline $\begin{array}{c}\text { Myristic } \mathrm{C}_{14-0} \\
\text { mg }\end{array}$ & 0.06 & Not found \\
\hline $\begin{array}{l}\text { Palmitic } \mathrm{C}_{16-0} \\
\mathrm{mg}\end{array}$ & 1.80 & Not found \\
\hline $\begin{array}{c}\text { Stearic } \mathrm{C}_{18-0}, \\
\mathrm{mg}\end{array}$ & 0.81 & Not found \\
\hline Oleic $\mathrm{C}_{18-1}, \mathrm{mg}$ & 47.30 & Not found \\
\hline $\begin{array}{c}\text { Linolic } \mathrm{C}_{18-2}, \\
\mathrm{mg}\end{array}$ & 48.77 & Not found \\
\hline
\end{tabular}

"Kalinovyi" syrup from dried/cut high cranberry fruits is inferior to that from the juice of fresh fruits in Vitamin C, polyphenols, pectin substances content, but contains fatty acids. High fatty acid content in the finished syrup is probably associated with the glyceropolymerization reaction on the co-heating and co-boiling of sugar syrup and dried high cranberry powder. 


\section{Conclusion}

Therefore, the university specialists revealed and substantiated the possibility of developing the "Kalinovyi" syrup based on the local raw materials with allowances made for human and technological resources for its manufacturing. In particular, it is a small business enterprise that, in partnership with the university, settled down to "widening the array" of syrups with a partial change of product framework.

Development peculiarities of the technology of the high cranberry fruit integrated processing are in the formation of the technical and technological pattern for the "Kalinovyi" syrup which determines its consumer appeal, offers the product's competitive advantages previously unknown in the market. Knowledge about the usefulness of high cranberry as a source of the whole array of micro- and macro-elements, minor food components necessary for normal functioning of the human body is a combination of traditional (high cranberry has been used in folk medicine since ancient times) and modern knowledge about completeness of the high cranberry chemical composition (health properties). The formation of business application pattern for the syrup was based on the facilities of the small business enterprise having the processing experience for fruit raw material with different technological properties and being ready for widening the array of syrups. The developed technological modes and parameters for manufacturing syrup from dried and cut high cranberry fruits were tested in real production settings. The comparative analysis of nutrition value of the syrups made from different raw material commodity forms: the juice of fresh high cranberry fruits and mixture of dried and cut whole high cranberry fruits has shown the practicability of the method developed and its implementation at a small business enterprise.

It is necessary to point out that the intellectual property right is the basis for innovation development of small business enterprises. Cooperation between the university and the enterprise resulted in the application for a patent for the manufacturing process of the "Kalinovyi" syrup from dried and cut high cranberry fruits.

\section{References}

[1] Strategy of scientific and technological development of the Russian Federation. Approved by the Presidential Decree from 01.12.2016, 642.

[2] I.S. Bukina, S.I. Chernykh, Innovations, J, 9, 15-21 (2016).

[3] V.C. Boichenko, Innovations, J, 9, 21-33 (2016).

[4] C.G. Polyakov, Organization and regulation of innovation activity: interaction of the state and the entrepreneurship, Monograph (2004).

[5] A.Y. Testova, Global challenges in economics and industry development, INDUSTRY-2016, papers of research-to-practice conference with foreign participation (21-23 March 2016).
[6] A.P. Garnov, O.V. Krasnobaeva, Human capital and vocational education, 2, 21-27 (2012).

[7] E.V. Kulikova, O. V. Kasenko, Innovational development of the economy, 3, 7-13 (2016).

[8] C.G. Polyakov, Innovations, J, 10, 3-10 (2016).

[9] C.G. Polyakov, A.P. Antropov, P.G. Gudkov, Innovations, J, 2, 62-65 (2019).

[10] A.S. Prokhorenkova, Innovations, J, 2, 84-90 (2019).

[11] P. A. Dvornichenko, V. O. Demchenko, V. K. Egorov, Innovations, J, 2, 90-98 (2019).

[12] Excellence and Opportunity: A science and innovation policy for the 21 st century, The Department of Trade and Industry DTI (2000).

[13] Investing and Innovation: A strategy for science, engineering and technology, HM Treasury, The Department of Trade and Industry DTI, Department for Education and Skills DFES (2002).

[14] The future is in knowledge and competence: Technology strategy - a review of choice, TAKES, The National Technology Agency (2002).

[15] Small Business Trade Hearing, Wash., 171-179 (2013).

[16] L. Leydesdorff, Journal of the Knowledge Economy, J, 3, 25-35 (2012).

[17] S.V. Novoselov, L.A. Mayurnikova, M.N. Klishina, The Kemerovo technological institute of food industry (2016).

[18] S.V. Novoselov, L.A. Mayurnikova, Methodology of food product projecting and promotion into the consumer market in innovational activities: Monograph (2013).

[19] T.V. Marshalkina, Innovations, J, 1, 115-120 (2015).

[20] E.I. Popova, V.F. Vinnitskaya, Bulletin of the Michyurinsk state university, 1, 222-225 (2012).

[21] V.F. Vinnitskaya, E.I. Popova, O.M. Blinnikova, Patent 2012111353, Russian Federation, MPK A23L 21/10, Method of manufacturing vegetable and fruit sauces with high cranberry "Kalisto", №2012111353/13, appl. 23.03.2012, pub. 27.09.2013.

[22] S.V. Frolova, V.F. Vinnitskaya, N.V. Andreeva, Patent 2011109194, Russian Federation, MPK A23L 2/02, Method of integrated waste-free processing of plant raw material for functional foods, no. 2011109194/13, appl. 11.03.2011, pub. 20.09.2012.

[23] O.I. Kvasenkov, Patent 2015154675, Russian Federation, MPK A23L 2/38, Method of obtaining kvass from high cranberry, no. 2015154675, appl. 21.12.2015, pub. 22.06.2017.

[24] Yu.V. Lavrinenko, I.A. Nikolaev, Patent 2700629, Russian Federation, MPKA23F 3/00, Herb tea composition (phyto-tea), no. 2018108287, appl. 06.03.2018, pub. 06.09.2019.

[25] M.I. Gladyshev, Journal of the Siberian Federal University, Biology series, J, 5, 352-386. 